\title{
Expected Effects of Offshore Wind Farms on Mediterranean Marine Life
}

\author{
Laura Bray 1,2,*, Sofia Reizopoulou ${ }^{2}$, Evangelos Voukouvalas ${ }^{3}$, Takvor Soukissian ${ }^{2}$, \\ Carme Alomar ${ }^{4}$, Maite Vázquez-Luis ${ }^{4}$, Salud Deudero ${ }^{4}$, Martin J. Attrill ${ }^{1}$ and \\ Jason M. Hall-Spencer ${ }^{1}$
}

1 Marine Institute, Plymouth University, Plymouth PL4 8AA, UK; m.attrill@plymouth.ac.uk (M.J.A.); jason.hall-spencer@plymouth.ac.uk (J.M.H.-S.)

2 Hellenic Centre for Marine Research, Institute of Oceanography, Athens-Souniou Ave 46.7 km, Anavissos, Attica 19013, Greece; sreiz@hcmr.gr (S.R.); tsouki@hcmr.gr (T.S.)

3 European Commission, Joint Research Centre (JRC), Institute for Environment and Sustainability, Climate Risk Management Unit, Via Enrico Fermi 2749, I-21027 Ispra (VA), Italia; evangelos.voukouvalas@ext.jrc.ec.europa.eu

4 Instituto Español de Oceanografía, Centro Oceanográfico de Baleares, Moll de Ponent s/n, 07015 Palma de Mallorca, Spain; c.alomar@ba.ieo.es (C.A.); maite.vazquez@ba.ieo.es (M.V.-L.); salud.deudero@ba.ieo.es (S.D.)

* Correspondence: lbray@hcmr.gr; Tel.: +30-229-107-6357

Academic Editor: Simon J. Watson

Received: 11 December 2015; Accepted: 14 February 2016; Published: 3 March 2016

\begin{abstract}
Current climate policy and issues of energy security mean wind farms are being built at an increasing rate to meet energy demand. As wind farm development is very likely in the Mediterranean Sea, we provide an assessment of the offshore wind potential and identify expected biological effects of such developments in the region. We break new ground here by identifying potential offshore wind farm (OWF) "hotspots" in the Mediterranean. Using lessons learned in Northern Europe, and small-scale experiments in the Mediterranean, we identify sensitive species and habitats that will likely be influenced by OWFs in both these hotspot areas and at a basin level. This information will be valuable to guide policy governing OWF development and will inform the industry as and when environmental impact assessments are required for the Mediterranean Sea.
\end{abstract}

Keywords: renewable energy; Mediterranean Sea; ecological impacts; marine energy

\section{Introduction}

The global demand for energy supply continues to increase rapidly [1]. Accelerated demographic and economic growth [2], modifications in energy usage as a result of climate change [3], and rising demands for rural electrification in many Middle East and North Africa (MENA) countries [4] have dramatically increased the energy demands of the Mediterranean region, a trend that is set to continue. Consequently, problems concerning the security of energy supply, and the impact of global warming and ocean acidification as a result of $\mathrm{CO}_{2}$ emissions, have stimulated research and development into environmentally sustainable energy. This drive is reflected in the Horizons 2020 EU Renewables Directive (2009/28/EC), with member states required to obtain $20 \%$ of their energy consumption from renewable energy sources by 2020 [5]. Non-EU Mediterranean countries have also recognized the need to decrease reliance on hydrocarbons and most have adopted similar policies [4].

Europe is seeing a rapid expansion of the wind energy sector on land; however, higher mean winds speeds due to a reduction in offshore surface roughness [6], and comparatively lower visual and noise pollution than onshore wind farms [7], has led to a recent expansion of marine wind farms with 
further planned developments particularly within the North Sea and Baltic regions [8]. As of 1 July 2014, the EU had a combined offshore capacity of $7343 \mathrm{MW}$, with a further 30,000 MW expected by $2020[5,9]$. Currently, the Mediterranean Sea has no operational offshore wind farms (OWFs) yet this is expected to go ahead imminently [10].

The environmental effects of OWF construction in the Mediterranean are as yet unknown. The Mediterranean has particular characteristics including minimal tidal ranges, high levels of biodiversity and endemism [11], and a high potential for range extension of alien species [12]. The region is also exposed to a suite of coastal pressures including pollution, busy shipping lanes, eutrophication, urban development, habitat degradation, and overfishing [13]. The effects of existing OWFs may not be directly applicable to the Mediterranean, highlighting the need for site-specific analyses before the commencement of large scale offshore developments. The aim of this paper is to systematically assess the biological effects of existing OWFs in Northern European Seas and consider those in relation to the unique conditions of the Mediterranean basin, to horizon-scan for the potential environmental effects and solutions if construction goes ahead.

\section{Methods}

The most important technical criteria for the identification of a suitable OWF sites are wind resource availability and bottom depth. Evidently, for a rational candidate site identification, additional technical criteria should be also considered, such as distance from shore, bottom morphology and type of sediments, electrical grid infrastructure, etc.; however, the most important criteria are wind resource availability and bottom depth.

The wind speed threshold levels and the depth criteria were set in accordance with the EEA (2009) recommendations regarding the economic vitality and the distance for the minimum optical nuisance requirements of the OWFs, respectively. Since the current fixed-bottom wind turbine technology (monopile, gravity-based, jacket and tripod foundations) is limited to water depths up to $50 \mathrm{~m}$, the depth range considered herewith is $20-50 \mathrm{~m}$, and the lower threshold for the mean annual wind speed at $80 \mathrm{~m}$ above mean sea level was set to $5 \mathrm{~ms}^{-1}$ [6]. According to the above restrictions, using 10-year results (1995-2004) obtained from the Eta-Skiron model: [14-16] and the General Bathymetry Chart of the Oceans global relief [16,17], potential wind energy sites (model grid points) were identified, while regions with high densities of such point locations were highlighted as offshore wind energy hotspots. The Eta-Skiron mesoscale meteorological model is a modified version of the non-hydrostatic Eta model and is used for the dynamical downscaling of the ECMWF Era-40 reanalysis data [17] and the ECMWF operational forecasts, with a fine spatial $\left(0.10^{\circ} \times 0.10^{\circ}\right)$ and temporal resolution $(3 \mathrm{~h})$ [16]. An evaluation of the Eta-Skiron model performance as regards the wind power density estimation for the Mediterranean Sea is presented in Soukissian, Papadopoulos [18].

Biological effects resulting from the construction, and operation, of OWFs were identified in a review of studies in Northern European Seas. Peer reviewed literature took precedence and primary literature was obtained from several databases including CAB abstracts, Google Scholar, Web of Science, Science Direct, and Scopus. Relevant grey literature was also included in the compilation of information, and expert opinions were sought from several research institutes and industry experts (references herein). For clarity, impacts were separated via taxa (e.g., birds, marine mammals, fish, benthos and plankton). Detailed evidence obtained via the literature review is presented in a table format within the supplementary information (Table S1-S6); where available, specific evidence regarding the impacts at OWF hotspots will be highlighted.

\section{Results and Discussion}

Although many Mediterranean coastlines seem poorly suited to OWF development, some large areas have exploitable potential, including the coasts of the Gulf of Lyons, the North Adriatic Sea, the entire coastal area of the Gulfs of Hammamet and Gabès in Tunisia, off the Nile River Delta, and the Gulf of Sidra in Libya (Figure 1). The five hotspots spatially cover the width and breadth of the 
Mediterranean Sea. Here, we consider the potential effects on birds, marine mammals, fish, benthos and plankton throughout the Mediterranean and, where available, the possible impacts of OWFs within the specific hotspot regions.

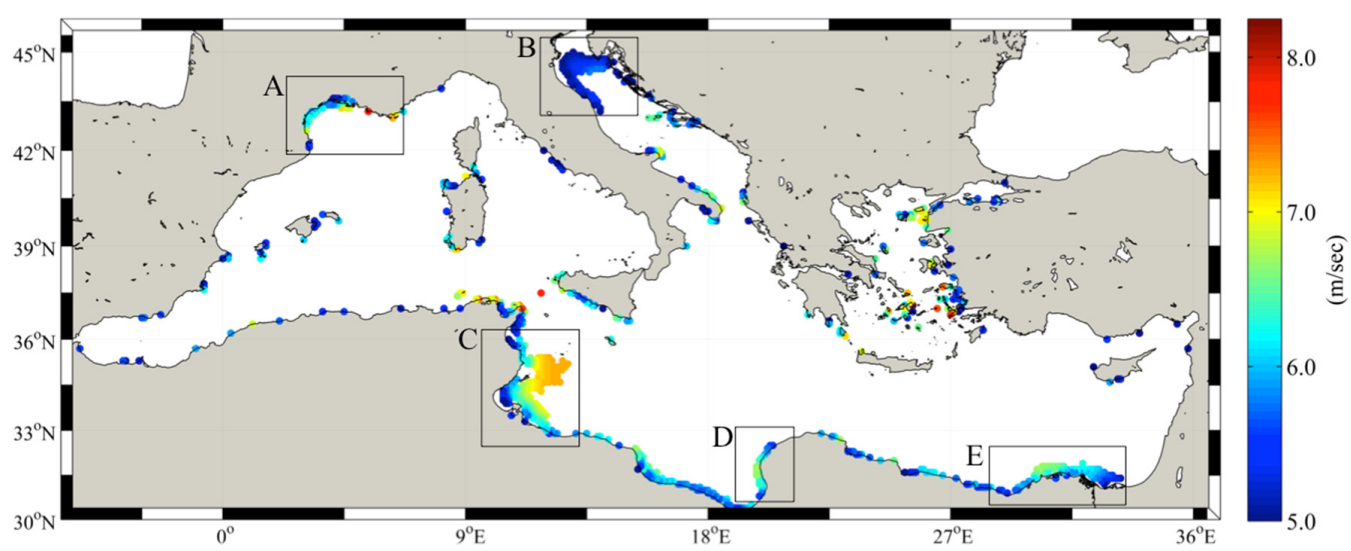

Figure 1. Locations which satisfy offshore wind development requirements of 20-50 m depth and an annual wind speed $>5 \mathrm{~ms}^{-1}$ at a height of $80 \mathrm{~m}$ above sea level. A: Gulf of Lion, B: North Adriatic Sea, C: Gulfs of Hammamet and Gabès, D: Gulf of Sidra, E: Nile Delta.

\subsection{Potential Effects of Mediterranean Offshore Wind Farms on Birds}

Wind farms affect resident and migrating birds, through avoidance behaviors, habitat displacement, and collision mortality, but such impacts are difficult to monitor offshore [19]. Seabirds that use the marine environment for foraging or resting may be displaced by OWFs [20]. The Mediterranean has a low diversity of seabirds, but these species tend to be long-lived with low fecundity, traits that often make species vulnerable to abrupt environmental change $[11,20]$ (Table 1). Fortunately, most Mediterranean marine birds are listed as "least concern" on the IUCN red list, although the Audouin's gull is listed as "near threatened," the Yelkouan shearwater as "vulnerable," and the Balearic shearwater as "critically endangered" [21]. All 16 Mediterranean countries have made commitments to protect these species at a national level [22]. With the exception of shearwaters [23], Mediterranean seabird populations appear to be increasing, particularly the yellow-legged gull $[11,24,25]$. These increases have been attributed to fish discards and improvements in coastal conservation [26-28], but changes to fishery discard practices following the reform of the Common Fisheries Policy may reverse this [29].

Studies of Northern European seabird populations have developed vulnerability indices to indicate seabirds likely to be affected by the presence of OWFs [30-32]. Using parameters that are heavily weighted on the risks of collision mortality (flight altitude, flight manoeuvrability, percentage of flight time, nocturnal flight altitude, disturbance by wind farm structures, ship and helicopter traffic, and habitat specialization), the North/Baltic Sea-based studies assessed 18 of the 29 Mediterranean seabirds. Notable exclusions to the list are the endemic species of the Mediterranean, which pose a greater conservation risk due to their small population sizes [33]. Garthe and Hüppop [13] identify the Black and Red-throated diver, the Sandwich tern, and the great Cormorant as the most sensitive of the Mediterranean seabirds within their index, and rated the Black-legged kittiwake, and the Black-headed gull as the least sensitive when all parameters were combined. Advancing this approach, Furness et al. [31] separated the hazards due to collision risk and habitat displacement. They identified the lesser black-backed gull and the Northern gannet as marine species sensitive to collision risk, and both the red and black-necked divers as most susceptible to long-term habitat displacement. These approaches lack any evaluation of species-specific OWF avoidance behavior and thus have large caveats attached to their findings. The approach of identifying at risk species via vulnerability indices is useful for the planning stages of OWFs; however, it does not determine if construction will have 
a detectable change in seabird population trends. Focus should preferably be given to understanding any direct effects OWFs will have on foraging success, e.g., diving behavior and prey characteristics, which in turn will impact reproductive success, juvenile survival and population trends [20].

Table 1. Mediterranean seabird sensitivity assessments highlighting most and least vulnerable species according to index. $\mathrm{Y}=$ Yes, $\mathrm{N}=\mathrm{No}$, Red $=10 \%$ most vulnerable Mediterranean species within index, Blue $=10 \%$ least vulnerable species within index, $"$-" = Index not applied.

\begin{tabular}{|c|c|c|c|c|c|c|}
\hline Common Name & Species & Endemic & $\begin{array}{l}\text { Listed under } \\
\text { Barcelona } \\
\text { Convention }\end{array}$ & $\begin{array}{l}\text { Wind Farm } \\
\text { Sensitivity } \\
\text { Index [13] }\end{array}$ & $\begin{array}{l}\text { Vulnerability } \\
\text { Index for } \\
\text { Collision } \\
\text { Impacts [30] }\end{array}$ & $\begin{array}{l}\text { Vulnerability } \\
\text { Index for } \\
\text { Disturbance } \\
\text { Impacts [30] }\end{array}$ \\
\hline $\begin{array}{l}\text { Cory's Shearwater } \\
\text { (Mediterranean) }\end{array}$ & $\begin{array}{c}\text { Calonectris diomedea } \\
\text { diomedea }\end{array}$ & Y & Y & - & - & - \\
\hline $\begin{array}{c}\text { Yelkouan } \\
\text { Shearwater } \\
\text { (Mediterranean) }\end{array}$ & Puffinus yelkouan & Y & $\mathrm{N}$ & - & - & - \\
\hline Balearic Shearwater & $\begin{array}{l}\text { Puffinus } \\
\text { mauretanicus }\end{array}$ & Y & $\mathrm{N}$ & - & - & - \\
\hline $\begin{array}{l}\text { European Shag } \\
\text { (Mediterranean) }\end{array}$ & $\begin{array}{c}\text { Phalacrocorax } \\
\text { aristotelis desmarestii }\end{array}$ & Y & Y & - & 150 & 14 \\
\hline Great Comorant & Phalacrocorax carbo & $\mathrm{N}$ & $\mathrm{N}$ & 23.3 & - & - \\
\hline Pygmy Comorant & $\begin{array}{l}\text { Phalacrocorax } \\
\text { pygmeus }\end{array}$ & $\mathrm{N}$ & $\mathrm{N}$ & - & - & - \\
\hline Audouin's gull & Larus audouinii & $\mathrm{N}$ & Y & - & - & - \\
\hline Little Gull & Hydrcoleus minutus & $\mathrm{N}$ & $\mathrm{N}$ & 12.8 & - & - \\
\hline $\begin{array}{l}\text { Lesser black-backed } \\
\text { gull }\end{array}$ & Larus fuscus & $\mathrm{N}$ & $\mathrm{N}$ & 13.8 & 960 & 3 \\
\hline Slender billed gull & Larus genei & $\mathrm{N}$ & Y & - & - & - \\
\hline Mediterranean gull & Larus melanocephalus & $\mathrm{N}$ & $\mathrm{Y}$ & - & - & - \\
\hline Black-headed gull & Larus ridibundus & $\mathrm{N}$ & $\mathrm{N}$ & 7.5 & - & - \\
\hline Caspian gull & Larus cachinnans & $\mathrm{N}$ & $\mathrm{N}$ & - & - & - \\
\hline $\begin{array}{l}\text { Black legged } \\
\text { kittiwake }\end{array}$ & Rissa tridactyla & $\mathrm{N}$ & $\mathrm{N}$ & 7.5 & & - \\
\hline Yellow legged gull & Larus michahellis & $\mathrm{N}$ & $\mathrm{N}$ & - & - & - \\
\hline Great skua & Catharacta skua & $\mathrm{N}$ & $\mathrm{N}$ & - & 320 & 3 \\
\hline Caspian tern & Hydroprogne caspia & $\mathrm{N}$ & $\mathrm{N}$ & - & - & - \\
\hline Common tern & Sterna hirundo & $\mathrm{N}$ & $\mathrm{N}$ & 15.0 & 229 & 8 \\
\hline Little tern & Sterna albifrons & $\mathrm{N}$ & $\mathrm{N}$ & - & 212 & 10 \\
\hline Sandwich tern & Sterna sandvicensis & $\mathrm{N}$ & $\mathrm{N}$ & 25.0 & 245 & 9 \\
\hline Lesser-crested tern & $\begin{array}{l}\text { Thalasseus } \\
\text { bengalensis }\end{array}$ & $\mathrm{N}$ & $\mathrm{N}$ & - & - & \\
\hline Razorbill & Alca torda & $\mathrm{N}$ & $\mathrm{N}$ & 15.8 & 32 & 14 \\
\hline Atlantic puffin & Fratercula arctica & $\mathrm{N}$ & $\mathrm{N}$ & 15.0 & 27 & 10 \\
\hline $\begin{array}{l}\text { European Storm } \\
\text { petrel }\end{array}$ & $\begin{array}{l}\text { Hydrobates pelagic } \\
\text { melitensis }\end{array}$ & Y & Y & - & 91 & 2 \\
\hline Northern gannet & Morus bassanus & $\mathrm{N}$ & $\mathrm{N}$ & - & - & - \\
\hline Osprey & Pandion haliaetus & $\mathrm{N}$ & Y & - & - & - \\
\hline Eleanore's falcon & Falco eleonorae & $\mathrm{N}$ & Y & - & - & - \\
\hline Red throated diver & Gavia stellata & $\mathrm{N}$ & $\mathrm{N}$ & 43.3 & 213 & 32 \\
\hline Black throated diver & Gavia arctica & $\mathrm{N}$ & $\mathrm{N}$ & 40.3 & 240 & 32 \\
\hline Great crested grebe & Podicep scristatus & $\mathrm{N}$ & $\mathrm{N}$ & 19.3 & 84 & 8 \\
\hline Red-necked grebe & Podiceps grisegena & $\mathrm{N}$ & $\mathrm{N}$ & 18.7 & - & - \\
\hline Eared grebe & Podiceps nigricollis & $\mathrm{N}$ & $\mathrm{N}$ & - & - & - \\
\hline
\end{tabular}


Threats to Mediterranean bird populations are also directed towards migratory species. Worldwide, migratory species are declining in greater numbers than resident populations [34], and the Mediterranean basin is a major transit route for Saharan-Eurasian migration, as evidenced by both the Mediterranean-Black Sea flyway and the Adriatic flyway [35,36]. Many long-distance bird migrants, e.g., raptors and storks, rely on land lift via thermal upwelling for long-distance flight $[37,38]$ and avoid broad fronts such as the Mediterranean Sea and the Saharan desert [37], creating bottlenecks at narrow passages of the Mediterranean Sea, including Gibraltar, the Straits of Sicily, Messina (Italy) and the Belen pass (Turkey) [39]. Wetlands around the Mediterranean provide suitable stopover sites for long-distance migrants to feed, rest and molt [40]. Some of the main wetlands around the Mediterranean are located within close proximity of potential OWF hotspots, particularly the Po Delta in the Northern Adriatic Sea the Nile Delta, the Gabès Delta and the Camargue Delta in the Gulf of Lion (Figure 2). Due to the bathymetry of the Mediterranean, and the steep continental slope of most coastlines, deltas provide feasible sites for wind farm constructions. High densities of avian habitat use in these regions means that OWF resource overlap will be a key factor in Mediterranean marine spatial planning in regard to OWFs.

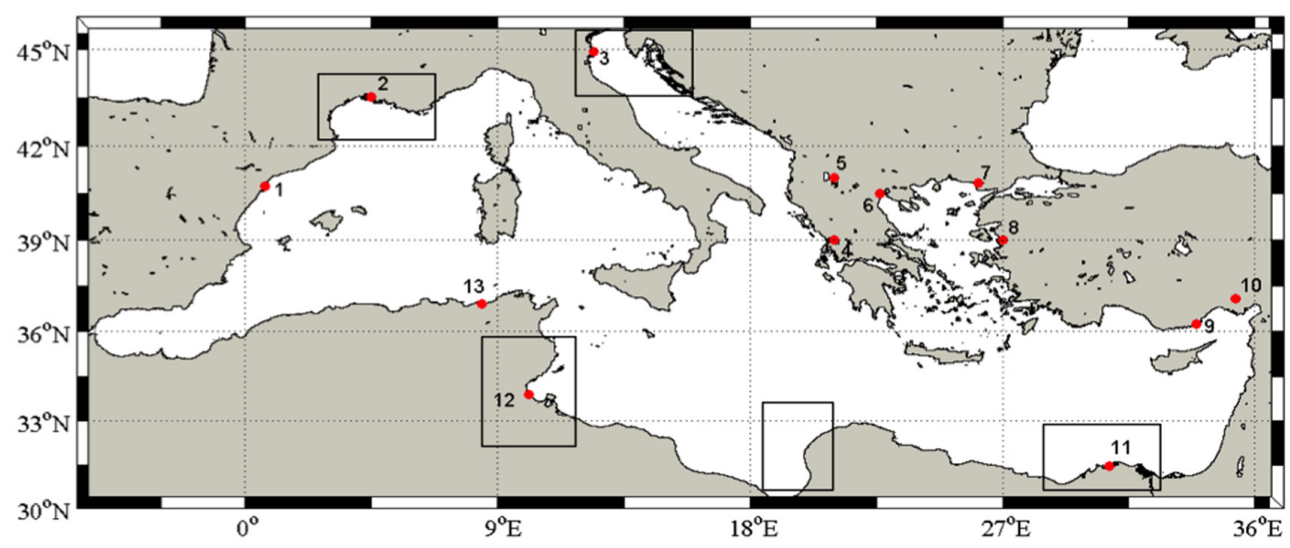

Figure 2. Main Mediterranean wetlands and overlapping OWF potential hotspot areas (adapted from [41]. 1. Ebro Delta; 2. Camargue Delta; 3. Po Delta; 4. Amvrakikos Gulf; 5. Prespa Basin; 6. Aliakmonas Delta; 7. Evros Delta; 8. Gediz Delta; 9. Göksu Delta; 10. Seyhan Delta; 11. Nile Delta; 12. Gabès Delta; 13. El Kala.

High collision levels of migrating terrestrial birds at well-lit observing platform during periods of bad weather and poor visibility [42] indicate that wind farms located near the coast, or prominent migration bottlenecks, may pose a significant risk to migrating birds. More recent evidence also shows alternative crossing options for some passerine species, including non-stop crossings over the Mediterranean Sea [43]. This indicates that species-specific migrations are not fixed either temporally or spatially, and individual route decisions are due to risk analysis of many parameters including energy reserves, weather conditions, and genetic disposition [44,45]. Until large-scale migration routes across the Mediterranean Sea are better understood, developers face large difficulties in wind farm spatial planning in the region. Obtaining this information is an essential task for potential OWF developers in the Mediterranean.

Aside from identifying crucial regions for migrating birds, one of the most poorly understood aspects about OWF effects on birds is avoidance behavior. Turbine avoidance tactics employed by a species may apply to both resident seabirds and long-distance migrants; however, any changes to migratory routes are extremely difficult to monitor and may have large, indirect effects [42]. Avoidance behavior is possible at several scales, which are typically classified into micro, meso, and macro strategies. Micro-avoidance is the behavioral response to actively avoid rotating blades. Meso-avoidance is classified as behavior whereby species that fly at rotor height within the wind 
farm and avoid the whole rotor swept zone and macro-avoidance being the behavioral alteration of a flight path due to the presence of a wind farm [46]. Macro-avoidance behavior strategies have been shown in some migrating individuals: The common eider Somateria mollissima, for example, exhibited avoidance behaviors of a wind turbine at a range of up to $500 \mathrm{~m}$ during the day [47]. The long-term consequences of employing avoidance techniques remain unclear. Among other parameters, real impacts to population trends of migrating birds will be highly dependent on the specific life histories of a species, expenditure of avoidance strategies, energy reserves, and weather conditions during migratory periods.

There are several possible measures to reduce the effects wind farms will have on Mediterranean avian populations, e.g., shutdown orders and changes to the phototaxis level of structures $[48,49]$. However, preventative initiatives are much more effective, i.e. ensuring planning and placement of OWFs are not in the vicinity of large population of species that have been identified as high risk within the Mediterranean. The sensitive species suggested here due to collision or habitat vulnerability include the lesser black-backed gull, the Northern gannet, and the red- and black-throated divers, while the endemic bird species and species whose populations are declining in recent decades (Shearwaters) are identified due to their conservation importance (Table 1). More understanding of the cumulative effects of all impacts, at all potential development sites, is needed. Until then, all future approaches in regard to OWF spatial planning in the Mediterranean should be of a cautionary nature.

\subsection{Potential Effects of Mediterranean Marine Mammals}

Marine mammals are often high profile, charismatic species and have the potential for high socio-economic value in their natural habitats [50]. It is therefore essential to understand the effects OWFs will have on Mediterranean populations. The Mediterranean Sea is home to both resident and visiting marine mammals, of which most are experiencing a decline in population trends, with the exception of visiting humpback whales whose numbers have appeared to increase [11,51]. At a basin level, total population numbers are difficult to assess with several species being classified as "data deficient" by the IUCN red list [20]. Nonetheless certain regions have been identified as important habitats for marine mammals. Monitoring programs show a high percentage of fin whale sightings within the Ligurian Sea in comparison with other regions of the Mediterranean Sea [52]. The Alborean Sea has been shown to be an important for long-finned pilot whale populations [53], and there is also evidence that due to the East-West basin migration of Sperm whales, either the Strait of Sicily, or the Strait of Messina are critical areas which enable migration [54].

In regard to OWF development, several resident marine mammals frequently use the coastal marine environment earmarked for potential developments including the critically endangered Mediterranean monk seal, the common Bottlenose dolphin, and visiting Humpback whales $[51,55,56]$. When assessing the combined species density of the resident marine mammals, the Gulf of Lion OWF hotspot displays the highest densities of resident marine mammals and as such can be considered as the most sensitive in regard to OWF development. The Gulfs of Hammamet and Gabès, the Gulf of Sidra, and the Nile Delta hotspots appear to support low populations of resident marine mammals (Figure 3).

The distribution of specific species of marine mammals is also of interest to developers. This is particularly true within the Northern Adriatic OWF hotspot. The Mediterranean monk frequently uses the coast of Croatia (Figure 1B, [57]), and the Bottlenose dolphins regularly sighted from the coast of Trieste and Kvarneric (Figure 1B, [55]). Other important areas for individual species include the the coast of Senigallia, and the Gulf of Gabes for the Humpback whale (Figure 1A,C) [51]. These regions will require particular attention during spatial planning stages of developers.

Through monitoring programs conducted in the Northern European seas, marine noise, and in particular pile driving during construction, has been identified as the biggest impact to marine mammals [58]. Increased motorized vessel shipping during the operational phase of wind farms also increases noise levels to the area, and so is also identified as an impact; however, this is not at a level 
expected to significantly affect marine mammals [59]. Depending on the hearing ranges of the species, pile driven construction has the ability to produce hearing impairment, although for most species, hearing reactions are as yet undetermined [60].

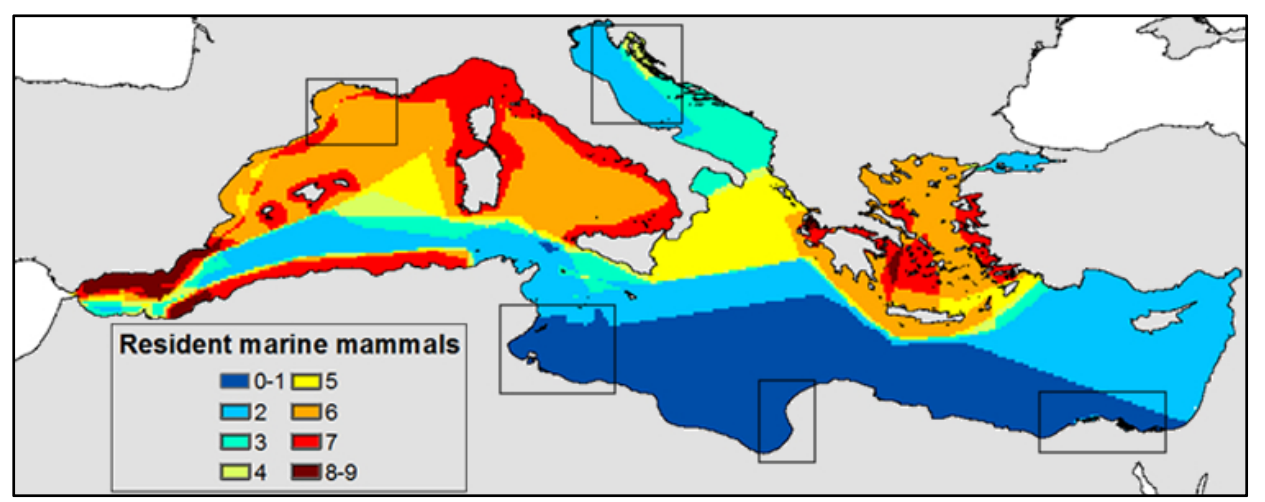

Figure 3. Species density of all resident marine mammals $(n=9)$ with overlay of OWF hotspots (Image adapted from Coll et al. [11]).

A study measuring the propagation of sound during the construction phase of an offshore site in the NE of Scotland implied Bottlenose dolphins would suffer auditory injury within a $100 \mathrm{~m}$ range of the site and behavior disturbances up to $50 \mathrm{~km}$ away [61]. With the use of T-POD porpoise detectors, acoustic monitoring during the construction and into the operational phase of the Nysted OWF indicated a possible change in habitat use by the harbor porpoise (Phocoena phocoena), with a reduction in the level of echolocation signals produced by the porpoises [62]. A long-term study (10 years) at the same wind farm also showed a decline from baseline levels of echolocation signals [63].

A similar study at the Dutch wind farm, Egmond aan Zee, after construction measured significantly higher acoustic activity inside the farm in comparison with a control site [64], and this trend was mirrored in a recent study of harbor seal (Phoca vitulina) foraging which suggested an increase in habitat utilization at two operational wind farms (Alpha Ventus and Sheringham Shoal) [65]. The repeated grid-like movements indicated for the first time, successful foraging behavior by an apex predator within an OWF. The apparent differences between probable habitat uses may be due to local-scale ecological differences, local population habituation of wind farms, or differences in construction type of wind farms [64]. Due to critical population levels in the Mediterranean, the observed increases in seal foraging behavior around wind farms may not be relevant to the Mediterranean monk seal [56,65].

In regard to the impacts of noise levels in the Mediterranean, the semi-enclosed Mediterranean also suffers from some of the highest volume of shipping routes in the world [66] (Figure 4). In general, noise from wind farms is influenced by water depth, wind speed, turbine type, wind farm size, and substratum type [67]; due to the high levels of existing background noise from maritime traffic in the Mediterranean, risks having a cumulative effect in masking communicative abilities of marine species [68]. When assessing the spatial density of traffic routes from 2013, the OWF hotspots of the Gulf of Lion, the North Adriatic Sea, and the Nile Delta show an already high density of vessels within the area (up to $140 \mathrm{~m}$ vessels. $\mathrm{km}^{-2}$. day ${ }^{-1}$ ); thus, high levels of background noise can be expected in these regions. The Gulf of Hammamet and Gabès, and the Gulf of Sidra suggest much lower levels of background noise stress. The use of underwater noise propagation models by policy makers will be required to understand the combined influence of OWF construction, operation and maintenance shipping with current levels of background noise at site-specific locations. 


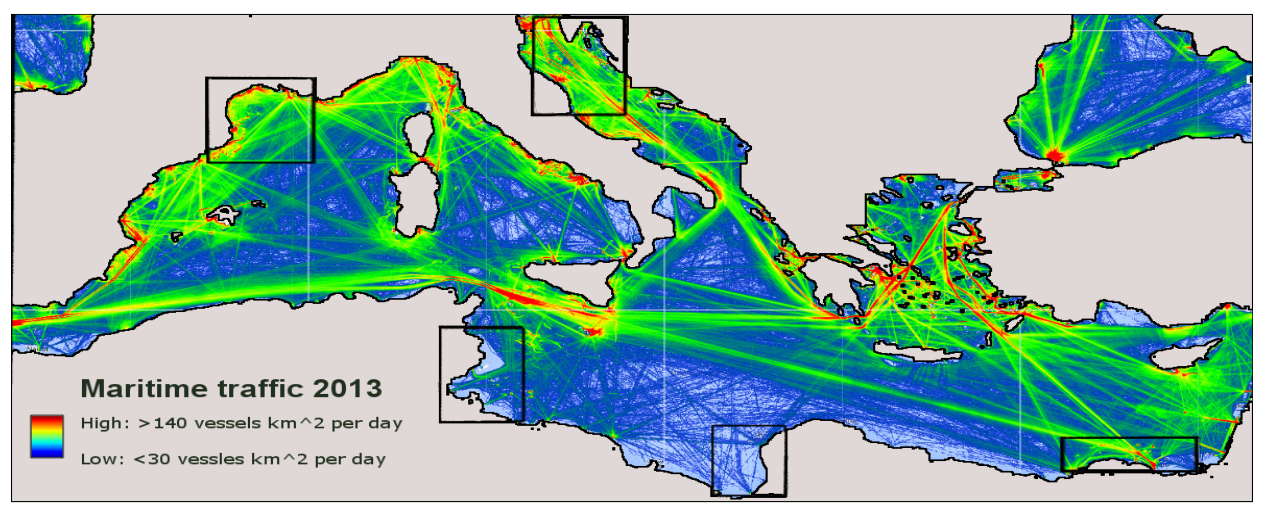

Figure 4. Combined density of 2013 maritime routes of all commercial vessels obtained via AIS vessel monitoring with overlay of OWF hotspots (source: www.marinetraffic.com).

\subsection{Potential Effects on Mediterranean Fish Communities}

Mediterranean coastal communities depend on fishing-related activities, particularly artisanal fishing, throughout the basin [69]. Of the 513 species and 6 subspecies of fish in the Mediterranean, $8 \%$ are currently classified as threatened by the IUCN [70], and there has been an alarming decline of Mediterranean fish stocks, with the largest declines in demersal fish stocks [71].

The principal impacts to fish populations caused by wind farms are noise, electro-magnetic fields, and novel habitat gain. Recent studies have shown that the noise generated by pile driving during the construction phase of OWF farms can generate acute stress responses in juvenile fish species. Although the responses were recorded as acute, it is possible that repeated and prolonged exposure in the wild may lead to a decrease in fitness [72]. During the operational stages of OWFs, evidence indicates fish permanently avoid wind turbines only at a range of up to $4 \mathrm{~m}$ under high wind speeds $\left(13 \mathrm{~ms}^{-1}\right)$, and that their ability to communicate and utilize orientation signals is masked [67]. Increased background noise and seabed vibration from operational OWFs and associated marine traffic will also influence fish detection distances [73,74] (Figure 4). Greater numbers of experimental studies on individual fish species are needed before we can fully comprehend the impact of anthropogenic noise on fish [75].

Electromagnetic fields occur around intra-turbine, array-to-transformer and transformer-to-shore cables. The electro-sensitivity of many marine species is unknown, and there is a dearth of peer-reviewed information regarding the effects of electro-magnetic fields. Elasmobranchs are thought to be especially sensitive, due to their electro-sensory organs [76]. Several shark and ray species react to wind farm cables [77], but whether this has any affect at the population level is unknown. Magnetic fields could influence geomagnetic patterns used by some migratory marine species for navigation [78], and reports also show that electro-magnetic fields from OWFs may affect fish migration. Gill et al. [79] identified eight migratory fish species sensitive to electromagnetic fields, including the European eel Anguilla anguilla, the Atlantic salmon Salmo salar and the Yellowfin tuna Thunnus albacares. Limited in situ data are available about the actual effects on fish, which rely on magnetic fields for migration; however, several studies in the Baltic Sea have indicated that the swimming speed of European eels is reduced in the vicinity of underwater electric cables [78,80]. However, due to the limited availability of empirical studies, it is difficult to theorize the extent of the impacts that electro-magnetic fields have on Mediterranean marine species and their fecundity.

The most direct influence on fisheries due to the presence of OWFs is likely the addition of novel, vertical habitat to an area previously void of hard substratum. Numerous studies have found greater abundances in fish around OWFs than in surrounding areas, such as Atlantic cod Gadus morhua, pouting Trisopterus luscus and several species of gobies [81-83]. Currently, most empirically measured effects due to operational wind turbines are temporally limited, and not at the scale of OWFs [60]. Several studies have implied that the new habitat provides increased foraging for both primary and secondary food resources, and protection grounds from currents [84]. There is much discussion 
between ecologists over whether changes in species biomass will be due to attraction or production [85]. Stomach content analysis and energy profiling have shown that OWFs are suitable feeding grounds for both Atlantic cod and pouting species [86,87], indicating that there is extra biomass available at the sites. Juvenile recruitment of Atlantic cod has also been observed at wind farms in the Belgium part of the North Sea [87]. Changes in prey densities may also be masked by predation rates [65,88], and will potentially strengthen predator avoidance behaviors like diel migration, further complicating the relationship between attraction-production dynamics [77]. While the mechanics of fish abundance at OWFs is not yet fully understood and requires additional analysis, it is becoming increasingly obvious that any ecological benefits will only be attained if fishing practices are banned within the wind farms [89].

For Mediterranean fish species, it is difficult to state the effects based on the findings of Northern European studies as there is a limited availability of information, and the majority of existing monitoring programs focus on species that are not generally present in Mediterranean waters, e.g., Atlantic cod $[82,85,88]$. That being said, there is evidence that suggests a yield increase of fish populations at wind farms as opposed to the simple attraction model previously hypothesized $[85,86]$. This is of particular importance for the Mediterranean, as levels of fishing are unsustainable, and most fish stocks are in decline [71]. The possibility for creating de facto marine protected areas (MPAs) due to fishing restrictions imposed within OWFs is an interesting aspect in the developments of OWFs in the Mediterranean Sea. It is clear that well protected MPAs in the Mediterranean result in significantly higher biomass than those with no or minimal protection [90], although many Mediterranean MPAs lack adequate protection [91]. Enforcement of fishing restrictions in Mediterranean MPAs is a difficult issue, but the benefit associated with designating an area within a series of fixed structures is that fishing regulations may be easier to enforce. Benthic fishermen are less willing to drag their trawling gear within turbines as they risk entanglement, and there is a potential to monitor fishing activity of static and recreational fishermen by using fixed cameras. It is worth noting, however, that displacement of fishing effort is a serious concern for the management of reduced fishing effort regions [92]. The production of sound by many fish species for communication during spawning periods means it is also essential for policy makers to identify fish spawning grounds during environmental impact assessments, with the aim of restricting OWF construction in these noise-sensitive areas [93].

\subsection{Potential Effects of Mediterranean Benthic Communities}

The Mediterranean harbors many important benthic habitats including vermetid reefs, coralligenic concentrations, shallow sublittoral rock, seamounts, deep-sea coral reefs, and abyssal plains [94,95]. The shallow sub-littoral sediment is a particularly valuable habitat for the Mediterranean benthos, as it is the preferred habitat of the endemic seagrass Posidonia oceanica, listed as a priority natural habitat under Annex 1 of the EC Habitats Directive (2/43/EEC on the Conservation of Natural Habitats and of Wild Fauna and Flora), due to its endemism, high productivity and provision of ecosystem services $[96,97]$. Favorable substrate conditions for OWF construction throughout Europe is typically soft sediment areas, and the piling and drilling of foundations and monopile jackets constitutes the most direct impact to the marine environment. As they favor similar habitats required for the construction of OWFs, Posidonia beds are at risk from direct physical destruction, sedimentation, and changes in hydrographic regimes. Conversely, construction may prevent local trawling and therefore decrease the amount of destructive fishing methods that typically reduces Posidonia coverage [98]. Any plans for OWFs in the Mediterranean Sea will have to be carefully designed around the distribution of Posidonia to ensure the correct conservation practices for this endemic, priority species.

Other impacts to soft sediment communities from pre-construction states include changes in regional current regimes, causing shifts in macro-benthic assemblages on a localized scale $[99,100]$. Studies have shown negative correlations between distance from turbines and grain sizes in the vicinity of turbines (measured from a distance from turbine of $15 \mathrm{~m}$ to $200 \mathrm{~m}$ ) in the Belgian part of the North Sea, which were also positively correlated with increases in organic matter and a shift in species 
assemblages. The closer to the turbine the soft sediment community samples were taken, the greater the increase in macrobenthic density and diversity [99].

Although changes in soft-sediment in-fauna are likely to be associated with wind farm construction, the most direct affect is the addition of hard substratum to the environment. Ecosystem shifts occur from changes in the existing soft sediment shifts and the addition of hard substratum in a habitat previously void of available settlement substratum. Recruitment and colonization of novel artificial habitats provided by turbine foundations increases the structural complexity and productivity of an environment previously low in in-fauna diversity and density [101-110].

Research at an offshore research platform in the German Bight indicated that 35 times more macro-zoobenthos biomass was associated with the additional hard substratum than the equivalent area of soft benthic sediment [81]. The increase in macro-zoobenthos biomass may appear beneficial in regard to productivity, yet in many cases species assemblages associated with artificial structures differ from the environment replaced and show lower levels of diversity than natural rock equivalents [81,110]. Long-term effects of ecosystem shifts are unknown, and species assemblages are influenced by many parameters including material and texture of offshore structures, larval supply, oceanographic conditions, temperature, salinity and water depth [111]. The number of defining parameters involved in influencing the spatial and temporal colonization of offshore artificial structures highlights the need for extensive area-specific research and long-tem in situ experiments to fully understand regional implications of OWFs.

With regard to the Mediterranean, the limited investigative work into epibenthic colonization has focused on concrete artificial reefs [112-114] or rock anthropogenic structures [115,116]. Most studies areas focus on the Northwestern region of the Mediterranean with the exception of two studies in Turkey and Israel $[117,118]$. Only two studies have investigated an offshore steel structure in the Mediterranean $[117,118]$. Dominating species of epibenthic assemblages varied depending on the location and duration of monitoring program, which ranged from 11 months to 20 years. Most studies cited the initial establishment of Hydozoa, Bryozoa and Serpulidae [112,117-120]. In several studies, initial colonization was followed with the establishment and dominance of the commercially farmed Mytilus galloprovincialis [112,115,119,120]. However, the establishment of mussel beds on artificial structures in the Mediterranean may be highly localized, as several artificial structures showed no such dominance $[117,121-123]$ or highly variable results [124]. The only long-term data set on a concrete artificial reef (20 years) reported five distinct phases of species assemblage: dominance of pioneer species, mussel dominance, mussel regression, mussels absence, and finally dominance of bryozoan bio-constructions [125]. Differences in the material used for offshore structures may have a significant effect on climax community composition; the two offshore, steel study sites in the Mediterranean offshore steel structures were both dominated by bivalves after 52 and 70 months [119,121].

The susceptibility of the Mediterranean Sea to non-indigenous species [126] and the colonization of artificial substrata in the Mediterranean by alien species [122,127] mean that wind farms may also act as benthic "stepping stones" that facilitate range extension of alien species within the Mediterranean marine environment, which in turn may potentially reduce the biodiversity of the basin $[111,128]$. Due to the apparent locality factor of benthic colonization communites, small-scale pilot studies are essential for understanding whether windfarms will proliferate alien species at potential wind farm locations. The use of before-after, control-impact studies by policy makers is strongly recommended.

\subsection{Potential Effects of Mediterranean Planktonic Communities}

The oxygen rich, oligotrophic waters of the semi-enclosed Mediterranean produce a low nutrient availability that is, however, generally intensified along both a west-east and north-south direction [129]. There is, nevertheless, a high spatial heterogeneity in the distribution of plankton throughout the Mediterranean Sea due to complex hydrodynamic circulation patterns forming multiple gyres and upwelling systems [130]. Most marine invertebrate and fish species have a planktonic larval stage; therefore, it is crucial to understand any effects OWFs may have on planktonic 
communities. There has been much speculation about the impacts caused by OWFs in relation to plankton $[6,107,110]$. Evidently, at some scale any offshore construction will have an effect on local hydrographic regimes [131]; however, the extent that this will affect upwelling/downwelling episodes, and thus potentially phytoplankton blooms, is currently unknown. Analytical models indicate that OWFs affect surface gravity waves underneath rotor blades [132,133], and there is much speculation in the literature as to the impacts any hydrographic changes will have on plankton/nekton aggregations [19]. OWFs may also affect planktonic populations by providing hard substrata that facilitate planktonic connectivity through larval settlement during dispersal processes [134-136]. The presence of available hard substratum from wind turbines for the recruitment and settlement of pelagic larvae have the potential to extend passive larval connectivity across biogeographic boundaries [134]. It is noted that there is a scarcity of information in the literature regarding the impacts OWFs will have on planktonic communities.

\section{Conclusions}

As the likelihood of Mediterranean OWFs increases, there is an ever-growing need to assess the biological costs and benefits of OWFs in the region. The aims of this horizon-scanning review were two-fold: firstly, to identify areas likely to be considered for the development of OWFs within the region, and, secondly, to identify the biological impacts of these developments.

The five OWF hotspots are identified as the Gulf of Lion, the North Adriatic Sea, the Gulfs of Hammamet and Gabès, the Gulf of Sidra, and the Nile Delta. Understanding the species, habitats and taxa that are likely to be affected by the construction and operation of OWFs in these regions and the wider Mediterranean region will assist developers and policy makers with future spatial planning decisions regarding OWFs within the Mediterranean. Furthermore, the advancement and implementation of floating wind turbine technology may diminish many of the above mentioned effects, which, from this point of view, is a very promising perspective for the near future.

Acknowledgments: This work was supported by project "Towards Coast to Coast NETworks of marine protected areas (from the shore to the high and deep sea), coupled with sea-based wind energy potential" (COCONET) from European Community's Seventh Framework Programme (FP7/2007-2013) under Grant Agreement No. 287844 project.

Author Contributions: L.B. conceived the investigation; E.V. and T.S. analyzed model output data; L.B., S.D., S.R., C.A., and M.V.-L. performed and analyzed data from the literature review; L.B., M.J.A., and J.M.H.-S. interpreted the results. L.B., M.J.A., and J.M.H.-S. wrote the paper.

Conflicts of Interest: The authors declare no conflict of interest.

\section{References}

1. Kermeli, K.; Graus, W.H.J.; Worrell, E. Energy efficiency improvement potentials and a low energy demand scenario for the global industrial sector. Energy Effic. 2014, 7, 987-1011. [CrossRef]

2. Esseghir, A.; Haouaoui Khouni, L. Economic growth, energy consumption and sustainable development: The case of the Union for the Mediterranean countries. Energy 2014, 71, 218-225. [CrossRef]

3. Cartalis, C.; Synodinou, A.; Proedrou, M.; Tsangrassoulis, A.; Santamouris, M. Modifications in energy demand in urban areas as a result of climate changes: An assessment for the southeast Mediterranean region. Energy Convers. Manag. 2001, 42, 1647-1656. [CrossRef]

4. Tsikalakis, A.; Tomtsi, T.; Hatziargyriou, N.D.; Poullikkas, A.; Malamatenios, C.; Giakoumelos, E.; Jaouad, O.C.; Chenak, A.; Fayek, A.; Matar, T.; et al. Review of best practices of solar electricity resources applications in selected Middle East and North Africa (MENA) countries. Renew. Sustain. Energy Rev. 2011, 15, 2838-2849. [CrossRef]

5. European Wind Energy Association (EWEA); Corbetta, G.; Pineda, I.; Wilkes, J. The European Offshore Wind Industry-Key Trends and Statistics 1st Half 2014; The European Wind Energy Association: Brussels, Belgium, 2014; p. 6.

6. European Environment Agency (EEA). Europe's Onshore and Offshore Wind Energy Potential: An Assessment of Environmental and Economic Constraints; EEA: Copenhagen, Denmark, 2009. 
7. Bilgili, M.; Yasar, A.; Simsek, E. Offshore wind power development in Europe and its comparison with onshore counterpart. Renew. Sustain. Energy Rev. 2011, 15, 905-915. [CrossRef]

8. Jacques, S.; Kreutzkamp, P.; Joseph, P. Seanergy 2020: Analysis of Planned/Suggested Offshore Electricity Infrastructure Relatively to Existing International MSP Instruments 2011; European Wind Energy Association: Brussels, Belgium, 2011.

9. European Wind Energy Association (EWEA); Moccia, J.; Arapogianni, A.; Wilkes, J.; Kjaer, C.; Gruet, R. Pure Power Wind Energy Targets for 2020 and 2030; European Wind Energy Association: Brussels, Belgium, 2011; p. 96.

10. De Decker, J.; Kreutzkamp, P.; Joesph, P.; Woyte, A.; Cowdroy, S.; Warland, L.; Svendsen, H.; Völker, J.; Funk, C.; Peinil, H.; et al. Offshore Electricity Grid Infrastructure in Europe; OffshoreGrid Final Report; OffshoreGrid: Brussels, Belgium, 2011.

11. Coll, M.; Piroddi, C.; Steenbeek, J.; Kaschner, K.; Ben Rais Lasram, F.; Aguzzi, J.; Ballesteros, E.; Bianchi, C.N.; Corbera, J.; Dailianis, T.; et al. The biodiversity of the Mediterranean Sea: Estimates, patterns, and threats. PLoS ONE 2010, 5, e11842. [CrossRef] [PubMed]

12. Zenetos, A.; Gofas, S.; Morri, C.; Rosso, A.; Violanti, D.; Garcia Raso, J.E.; Cinar, M.E.; Almogi-Labin, A.; Ates, A.S.; Azzurro, E.; et al. Alien species in the Mediterranean Sea by 2012. A contribution to the application of European Union's Marine Strategy Framework Directive (MSFD). Part 2. Introduction trends and pathways. Mediterr. Mar. Sci. 2012, 13. [CrossRef]

13. Micheli, F.; Halpern, B.S.; Walbridge, S.; Ciriaco, S.; Ferretti, F.; Fraschetti, S.; Lewison, R.; Nykjaer, L.; Rosenberg, A.A. Cumulative human impacts on mediterranean and black sea marine ecosystems: Assessing current pressures and opportunities. PLoS ONE 2013, 8, e79889. [CrossRef] [PubMed]

14. Papadopoulos, A.; Katsafados, P. Verification of operational weather forecasts from the POSEIDON system across the Eastern Mediterranean. Nat. Hazards Earth Syst. Sci. 2009, 9, 1299-1306. [CrossRef]

15. Papadopoulos, A.; Kallos, G.; Katsafados, P.; Nickovic, S. The Poseidon weather forecasting system: An overview. Glob. Atmos. Ocean Syst. 2002, 8, 219-237. [CrossRef]

16. Papadopoulos, A.; Korres, G.; Katsafados, P.; Ballas, D.; Perivoliotis, L.; Nittis, K. Dynamic downscaling of the ERA-40 data using a mesoscale meteorological model. Mediterr. Mar. Sci. 2011, 12. [CrossRef]

17. Uppala, S.M.; KÅllberg, P.W.; Simmons, A.J.; Andrae, U.; Bechtold, V.D.C.; Fiorino, M.; Gibson, J.K.; Haseler, J.; Hernandez, A.; Kelly, G.A.; et al. The ERA-40 re-analysis. Q. J. R. Meteorol. Soc. 2005, 131, 2961-3012. [CrossRef]

18. Soukissian, T.H.; Papadopoulos, A. Effects of different wind data sources in offshore wind power assessment. Renew. Energy 2015, 77, 101-114. [CrossRef]

19. Desholm, M.; Kahlert, J. Avian collision risk at an offshore wind farm. Biol. Lett. 2005, 1, 296-298. [CrossRef] [PubMed]

20. Scott, B.E.; Langton, R.; Philpott, E.; Waggitt, J.J. Seabirds and Marine Renewables: Are We Asking the Right Questions? In Marine Renewable Energy Technology and Environmental Interactions; Shields, M.A., Payne, A.I.L., Eds.; Springer Netherlands: Dordrecht, The Netherlands, 2014; pp. 81-92.

21. The IUCN Red List of Threatened Species. Version 2014.2. Available online: http:/ /www. iucnredlist.org (accessed on 28 August 2014).

22. United Nations Environment Programme-Mediterranean Action Plan (UNEP-MAP). Protocol Concerning Specially Protected Areas and Biological Diversity in the Mediterranean; UNEP/Map Publications: Athens, Greece, $1999 ;$ p. 3.

23. Cooper, J.; Baccetti, N.; Belda, E.J.; Borg, J.J.; Oro, D.; Papaconstantinou, C.; Sánchez, A. Seabird mortality from longline fishing in the Mediterranean Sea and Macaronesian waters: A review and a way forward. Sci. Mar. 2003, 67, 57-64. [CrossRef]

24. Bourgeois, K.; Vidal, E. The endemic Mediterranean yelkouan shearwater Puffinus yelkouan: Distribution, threats and a plea for more data. Oryx 2008, 42, 187-194. [CrossRef]

25. Thibault, J.C.; Zotier, R.; Guyot, I.; Bretagnolle, V. Recent trends in breeding marine birds of the Mediterranean region with special reference to Corsica. Colon Waterbirds 1996, 19, 31-40. [CrossRef]

26. Donald, P.F.; Sanderson, F.J.; Burfield, I.J.; Bierman, S.M.; Gregory, R.D.; Waliczky, Z. International conservation policy delivers benefits for birds in Europe. Science 2007, 317, 810-813. [CrossRef] [PubMed]

27. Oro, D. Effects of trawler discard availability on egg laying and breeding success in the lesser black-backed gull Larus fuscus in the western Mediterranean. Mar. Ecol. Prog. Ser. 1996, 132, 43-46. [CrossRef] 
28. Oro, D.; Ruiz, X. Exploitation of trawler discards by breeding seabirds in the north-western Mediterranean: Differences between the Ebro Delta and the Balearic Islands areas. ICES J. Mar. Sci. 1997, 54, 695-707. [CrossRef]

29. Bicknell, A.W.J.; Oro, D.; Camphuysen, K.; Votier, S.C. Potential consequences of discard reform for seabird communities. J. Appl. Ecol. 2013, 50, 649-658. [CrossRef]

30. Bradbury, G.; Trinder, M.; Furness, B.; Banks, A.N.; Caldow, R.W.G.; Hume, D. Mapping seabird sensitivity to offshore wind farms. PLoS ONE 2014, 9, e106366. [CrossRef] [PubMed]

31. Furness, R.W.; Wade, H.M.; Masden, E.A. Assessing vulnerability of marine bird populations to offshore wind farms. J. Environ. Manag. 2013, 119, 56-66. [CrossRef] [PubMed]

32. Garthe, S.; Hüppop, O. Scaling possible adverse effects of marine wind farms on seabirds: Developing and applying a vulnerability index. J. Appl. Ecol. 2004, 41, 724-734. [CrossRef]

33. Gallo-Orsi, U. Species Action Plans for the conservation of seabirds in the Mediterranean Sea: Audouin's gull, Balearic shearwater and Mediterranean shag. Sci. Mar. 2003, 67 (Suppl. 2), 47-55. [CrossRef]

34. Wilcove, D.S.; Wikelski, M. Going, going, gone: Is animal migration disappearing. PLoS Biol. 2008, 6, e188. [CrossRef] [PubMed]

35. Boere, G.C.; Stroud, D.A. The Flyway Concept: What It Is and What It Isn't; The Stationery Office: Edinburgh, UK, 2006; pp. 40-47.

36. Denac, D.; Schneider-Jacoby, M.; Stumberger, B. Adriatic Flyway: Closing the Gap in Bird Conservation; Euronatur: Liboa, Portugal, 2010.

37. Alerstam, T.; Pettersson, S.G. Why do migrating birds fly along coastlines? J. Theor. Biol. 1977, 65, 699-712. [CrossRef]

38. Pennycuick, C.J. Soaring behavior and performance of some east African birds, observed from a motor-glider. IBIS 1972, 114, 178-218. [CrossRef]

39. Bijlsma, R.G. Bottleneck Areas for Migratory Birds in the Mediterranean Region: An Assessment of the Problems and Recommendations for Action; ICBP: Cambridge, UK, 1987; Volume 18.

40. Kirby, J.S.; Stattersfield, A.J.; Butchart, S.H.M.; Evans, M.I.; Grimmett, R.F.A.; Jones, V.R.; O'Sullivan, J.; Tucker, G.M.; Newton, I. Key conservation issues for migratory land- and waterbird species on the world's major flyways. Bird Conserv. Int. 2008, 18, S49-S73. [CrossRef]

41. Jourdain, E.; Gauthier-Clerc, M.; Bicout, D.; Sabatier, P. Bird Migration Routes and Risk for Pathogen Dispersion into Western Mediterranean Wetlands. Emerg Infect Dis 2007, 13, 365-372. [CrossRef] [PubMed]

42. Hüppop, O.; Dierschke, J.; Exo, K.-M.; Fredrich, E.; Hill, R. Bird migration studies and potential collision risk with offshore wind turbines. IBIS 2006, 148, 90-109. [CrossRef]

43. Biebach, H.; Biebach, I.; Friedrich, W.; Heine, G.; Partecke, J.; Schmidl, D. Strategies of passerine migration across the Mediterranean Sea and the Sahara Desert: A radar study. IBIS 2000, 142, 623-634. [CrossRef]

44. Alerstam, T.; Lindström, Å. Optimal bird migration: The relative importance of time, energy, and safety. In Bird Migration; Gwinner, P.D.E., Ed.; Springer: Berlin, Germany, 1990; pp. 331-351.

45. Gschweng, M.; Kalko, E.K.V.; Querner, U.; Fiedler, W.; Berthold, P. All across Africa: Highly individual migration routes of Eleonora's falcon. Proc. Biol. Sci. 2008, 275, 2887-2896. [CrossRef] [PubMed]

46. Wildfowl and Wetlands Trust (WWT). Strategic assessment of collision risk of Scottish offshore wind farms to migrating birds. Scottish Marine and Freshwater Science; Scottish Government: Edinburgh, UK, 2014; Volume 5.

47. Masden, E.A.; Reeve, R.; Desholm, M.; Fox, A.D.; Furness, R.W.; Haydon, D.T. Assessing the impact of marine wind farms on birds through movement modelling. J. R. Soc. Interface 2012, 9, 2120-2130. [CrossRef] [PubMed]

48. Poot, H.; Ens, B.J.; de Vries, H.; Donners, M.A.; Wernand, M.R.; Marquenie, J.M. Green light for nocturnally migrating birds. Ecol. Soc. 2008, 13, 47.

49. Saidur, R.; Rahim, N.A.; Islam, M.R.; Solangi, K.H. Environmental impact of wind energy. Renew. Sustain. Energy Rev. 2011, 15, 2423-2430. [CrossRef]

50. Notarbartolo-di-Sciara, G.; Agardy, T.; Hyrenbach, D.; Scovazzi, T.; van Klaveren, P. The Pelagos Sanctuary for Mediterranean marine mammals. Aquat. Conserv. Mar. Freshw. Ecosyst. 2008, 18, 367-391. [CrossRef]

51. Frantzis, A.; Nikolaou, O.; Bompar, J.M.; Cammedda, A. Humpback whale (Megaptera novaeangliae) occurrence in the Mediterranean Sea. J. Cetacean Res. Manag. 2004, 6, 25-28.

52. Notarbartolo-Di-Sciara, G.; Zanardelli, M.; Jahoda, M.; Panigada, S.; Airoldi, S. The fin whale Balaenoptera physalus (L. 1758) in the Mediterranean Sea. Mamm. Rev. 2003, 33, 105-150. [CrossRef] 
53. Cañadas, A.; Sagarminaga, R. The Northeastern Alboran Sea, an important breeding and feeding ground for the long-finned pilot whale (Globicephala Melas) in the Mediterranean Sea. Mar. Mammal Sci. 2000, 16, 513-529. [CrossRef]

54. Frantzis, A.; Airoldi, S.; Notarbartolo-di-Sciara, G.; Johnson, C.; Mazzariol, S. Inter-basin movements of Mediterranean sperm whales provide insight into their population structure and conservation. Deep Sea Res. I 2011, 58, 454-459. [CrossRef]

55. Bearzi, G.; Fortuna, C.M.; Reeves, R.R. Ecology and conservation of common bottlenose dolphins Tursiops truncatus in the Mediterranean Sea. Mammal Rev. 2009, 39, 92-123. [CrossRef]

56. Dendrinos, P.; Karamanlidis, A.A.; Kotomatas, S.; Paravas, V.; Adamantopoulou, S. Report of a New Mediterranean monk seal (Monachus monachus) breeding colony in the Aegean Sea, Greece. Aquat. Mamm. 2008, 34, 355-361. [CrossRef]

57. Gomerčić, T.; Huber, D.; Gomerčić, M.; Gomerčić, H. Presence of the Mediterranean monk seal (Monachus monachus) in the Croatian part of the Adriatic Sea. Aquat. Mamm. 2011, 37, 243-247. [CrossRef]

58. Thomsen, F.; Lüdemann, K.; Kafemann, R.; Piper, W. Effects of Offshore Wind Farm Noise on Marine Mammals and Fish; Germany on Behalf of COWRIE Ltd.: Hamburg, Germany, 2006.

59. Madsen, P.; Wahlberg, M.; Tougaard, J.; Lucke, K.; Tyack, P. Wind turbine underwater noise and marine mammals: Implications of current knowledge and data needs. Mar. Ecol. Prog. Ser. 2006, 309, 279-295. [CrossRef]

60. Bergström, L.; Kautsky, L.; Malm, T.; Rosenberg, R.; Wahlberg, M.; Capetillo, N.Å.; Wilhelmsson, D. Effects of offshore wind farms on marine wildlife-A generalized impact assessment. Environ. Res. Lett. 2014, 9, 034012. [CrossRef]

61. Bailey, H.; Clay, G.; Coates, E.A.; Lusseau, D.; Senior, B.; Thompson, P.M. Using T-PODs to assess variations in the occurrence of coastal bottlenose dolphins and harbor porpoises. Aquat. Conserv. Mar. Freshw. Ecosyst. 2010, 20, 150-158. [CrossRef]

62. Carstensen, J.; Henriksen, O.D.; Teilmann, J. Impacts of offshore wind farm construction on harbor porpoises: Acoustic monitoring of echo-location activity using porpoise detectors (T-PODs). Mar. Ecol. Prog. Ser. 2006, 321, 295-308. [CrossRef]

63. Teilmann, J.; Carstensen, J. Negative long term effects on harbor porpoises from a large scale offshore wind farm in the Baltic-Evidence of slow recovery. Environ. Res. Lett. 2012, 7, 045101. [CrossRef]

64. Scheidat, M.; Tougaard, J.; Brasseur, S.; Carstensen, J.; van Polanen Petel, T.; Teilmann, J.; Reijnders, P. Harbour porpoises (Phocoena phocoena) and wind farms: A case study in the Dutch North Sea. Environ. Res. Lett. 2011, 6, 025102. [CrossRef]

65. Russell, D.J.F.; Brasseur, S.M.; Thompson, D.; Hastie, G.D.; Janik, V.M.; Aarts, G.; McClintock, B.T.; Matthiopoulos, J.; Moss, S.E.W.; McConnell, B. Marine mammals trace anthropogenic structures at sea. Curr. Biol. 2014, 24, R638-R639. [CrossRef] [PubMed]

66. Abdulla, A. Maritime Traffic Effects on Biodiversity in the Mediterranean Sea: Review of Impacts, Priority Areas and Mitigation Measures; IUCN: Gland, Switzerland, 2008; Volume 1.

67. Bailey, H.; Senior, B.; Simmons, D.; Rusin, J.; Picken, G.; Thompson, P.M. Assessing underwater noise levels during pile-driving at an offshore windfarm and its potential effects on marine mammals. Mar. Pollut. Bull. 2010, 60, 888-897. [CrossRef] [PubMed]

68. David, J.A. Likely sensitivity of bottlenose dolphins to pile-driving noise. Water Environ. J. 2006, 20, 48-54. [CrossRef]

69. Tzanatos, E.; Dimitriou, E.; Papaharisis, L.; Roussi, A.; Somarakis, S.; Koutsikopoulos, C. Principal socio-economic characteristics of the Greek small-scale coastal fishermen. Ocean Coast. Manag. 2006, 49, 511-527. [CrossRef]

70. Malak, D.A. Overview of the Conservation Status of the Marine Fishes of the Mediterranean Sea; IUCN: Gland, Switzerland, 2011.

71. Vasilakopoulos, P.; Maravelias, C.D.; Tserpes, G. The alarming decline of Mediterranean fish stocks. Curr. Biol. 2014, 24, 1643-1648. [CrossRef] [PubMed]

72. Debusschere, E.; Coensel, B.D.; Vandendriessche, S.; Botteldooren, D.; Hostens, K.; Vincx, M.; Degraer, S. Effects of offshore wind farms on the early life stages of Dicentrarchus Labrax. In The Effects of Noise on Aquatic Life II; Popper, A.N., Hawkins, A., Eds.; Springer: New York, NY, USA, 2016; pp. 197-204.

73. Wahlberg, M.; Westerberg, H. Hearing in fish and their reactions to sounds from offshore wind farms. Mar. Ecol. Prog. Ser. 2005, 288, 295-309. [CrossRef] 
74. Sigray, P.; Andersson, M.H. Particle motion measured at an operational wind turbine in relation to hearing sensitivity in fish. J. Acoust. Soc. Am. 2011, 130, 200-207. [CrossRef] [PubMed]

75. Radford, A.N.; Kerridge, E.; Simpson, S.D. Acoustic communication in a noisy world: Can fish compete with anthropogenic noise? Behav. Ecol. 2014, 25, 1022-1030. [CrossRef]

76. Tricas, T.; Gill, A.B. Effects of EMFs from Undersea Power Cables on Elasmobranchs and Other Marine Species; U.S. Dept. of the Interior: Camirillo, CA, USA, 2011; p. 426.

77. Gill, A.B.; Taylor, H. The Potential Effects of Electromagnetic Fields Generated by Cabling between Offshore Wind Turbines upon Elasmobranch Fishes; Countryside Council for Wales and University of Liverpool: Bangor, UK, 2001; p. 60.

78. Öhman, M.C.; Sigray, P.; Westerberg, H. Offshore windmills and the effects of electromagnetic fields on fish. AMBIO 2007, 36, 630-633. [CrossRef]

79. Gill, A.B.; Bartlett, M.; Thomsen, F. Potential interactions between diadromous fishes of U.K. conservation importance and the electromagnetic fields and subsea noise from marine renewable energy developments. J. Fish Biol. 2012, 81, 664-695. [CrossRef] [PubMed]

80. Westerberg, H.; Lagenfelt, I. Sub-sea power cables and the migration behaviour of the European eel. Fish. Manag. Ecol. 2008, 15, 369-375. [CrossRef]

81. Krone, R.; Gutow, L.; Joschko, T.J.; Schröder, A. Epifauna dynamics at an offshore foundation-Implications of future wind power farming in the North Sea. Mar. Environ. Res. 2013, 85, 1-12. [CrossRef] [PubMed]

82. Reubens, J.T.; Braeckman, U.; Vanaverbeke, J.; van Colen, C.; Degraer, S.; Vincx, M. Aggregation at windmill artificial reefs: CPUE of Atlantic cod (Gadus morhua) and pouting (Trisopterus luscus) at different habitats in the Belgian part of the North Sea. Fish. Res. 2013, 139, 28-34. [CrossRef]

83. Wilhelmsson, D.; Malm, T.; Öhman, M.C. The influence of offshore windpower on demersal fish. ICES J. Mar. Sci. 2006, 63, 775-784. [CrossRef]

84. Wilson, J.C.; Elliott, M. The habitat-creation potential of offshore wind farms. Wind Energy 2009, 12, $203-212$. [CrossRef]

85. Reubens, J.T.; Degraer, S.; Vincx, M. The ecology of benthopelagic fishes at offshore wind farms: A synthesis of 4 years of research. Hydrobiologia 2014, 727, 121-136. [CrossRef]

86. De Troch, M.; Reubens, J.T.; Heirman, E.; Degraer, S.; Vincx, M. Energy profiling of demersal fish: A case-study in wind farm artificial reefs. Mar. Environ. Res. 2013, 92, 224-233. [CrossRef] [PubMed]

87. Reubens, J.T.; de Rijcke, M.; Degraer, S.; Vincx, M. Diel variation in feeding and movement patterns of juvenile Atlantic cod at offshore wind farms. J. Sea Res. 2014, 85, 214-221. [CrossRef]

88. Bergström, L.; Sundqvist, F.; Bergstrm, U. Effects of an offshore wind farm on temporal and spatial patterns in the demersal fish community. Mar. Ecol. Prog. Ser. 2013, 485, 199-210. [CrossRef]

89. Wilhelmsson, D.; Langhamer, O. The influence of fisheries exclusion and addition of hard substrata on fish and crustaceans. In Marine Renewable Energy Technology and Environmental Interactions; Shields, M.A., Payne, A.I.L., Eds.; Springer Netherlands: Dordrecht, The Netherlands, 2014; pp. 49-60.

90. Guidetti, P.; Baiata, P.; Ballesteros, E.; di Franco, A.; Hereu, B.; Macpherson, E.; Micheli, F.; Pais, A.; Panzalis, P.; Rosenberg, A.A.; et al. Large-scale assessment of Mediterranean marine protected areas effects on fish assemblages. PLoS ONE 2014, 9, e91841. [CrossRef] [PubMed]

91. Montefalcone, M.; Albertelli, G.; Morri, C.; Parravicini, V.; Bianchi, C.N. Legal protection is not enough: Posidonia oceanica meadows in marine protected areas are not healthier than those in unprotected areas of the northwest Mediterranean Sea. Mar. Pollut. Bull. 2009, 58, 515-519. [CrossRef] [PubMed]

92. Halpern, B.S.; Gaines, S.D.; Warner, R.R. Confounding effects of the export of production and the displacement of fishing effort from marine reserves. Ecol. Appl. 2004, 14, 1248-1256. [CrossRef]

93. Slabbekoorn, H.; Bouton, N.; van Opzeeland, I.; Coers, A.; ten Cate, C.; Popper, A.N. A noisy spring: The impact of globally rising underwater sound levels on fish. Trends Ecol. Evol. 2010, 25, 419-427. [CrossRef] [PubMed]

94. Danovaro, R.; Company, J.B.; Corinaldesi, C.; D’Onghia, G.; Galil, B.; Gambi, C.; Gooday, A.J.; Lampadariou, N.; Luna, G.M.; Morigi, C.; et al. Deep-sea biodiversity in the Mediterranean Sea: The known, the unknown, and the unknowable. PLoS ONE 2010, 5, e11832. [CrossRef] [PubMed]

95. Mo, G.; Agnesi, S.; Evans, D.; Populus, J.; Tunesi, L. Mediterranean benthic EUNIS habitats: Structural considerations and lessons learned from mapping. Rev. Investig. Mar. 2012, 19, 48-50. 
96. Vassallo, P.; Paoli, C.; Rovere, A.; Montefalcone, M.; Morri, C.; Bianchi, C.N. The value of the seagrass Posidonia oceanica: A natural capital assessment. Mar. Pollut. Bull. 2013, 75, 157-167. [CrossRef] [PubMed]

97. Jackson, E.L.; Rees, S.E.; Wilding, C.; Attrill, M.J. Use of a seagrass residency index to apportion commercial fishery landing values and recreation fisheries expenditure to seagrass habitat service. Conserv. Biol. 2015, 29, 899-909. [CrossRef] [PubMed]

98. Sanchezjerez, P. Effect of an artificial reef in Posidonia meadows on fish assemblage and diet of Diplodus annularis. ICES J. Mar. Sci. 2002, 59, S59-S68. [CrossRef]

99. Coates, D.A.; Deschutter, Y.; Vincx, M.; Vanaverbeke, J. Enrichment and shifts in macrobenthic assemblages in an offshore wind farm area in the Belgian part of the North Sea. Mar. Environ. Res. 2014, 95, 1-12. [CrossRef] [PubMed]

100. De Backer, A.; van Hoey, G.; Coates, D.; Vanaverbeke, J.; Hostens, K. Similar diversity-disturbance responses to different physical impacts: Three cases of small-scale biodiversity increase in the Belgian part of the North Sea. Mar. Pollut. Bull. 2014, 84, 251-262. [CrossRef] [PubMed]

101. Birklund, J.; Petersen, A.H. Development of the Fouling Community on Turbine Foundations and Scour Protections in Nysted Offshore Wind Farm, 2003; Report Energi E2 A/S; DHI Water and Environment: Hørsholm, Denmark, 2004.

102. Kerckhof, F.; Norro, A.; Jacques, T.; Degraer, S. Early colonization of a concrete offshore windmill foundation by marine biofouling on the Thornton Bank (southern North Sea). In Offshore Wind Farms in the Belgian Part of the North Sea: State of the Art after Two Years of Environmental Monitoring; Royal Belgian Institute of Natural Sciences: Brussel, Belgium, 2009.

103. Kerckhof, F.; Rumes, B.; Norro, A.; Jacques, T.G.; Degraer, S. Seasonal variation and vertical zonation of the marine biofouling on a concrete offshore windmill foundation on the Thornton Bank (southern North Sea). In Offshore Wind Farms in the Belgian Part of the North Sea: State of the Art after Two Years of Environmental Monitoring; Royal Belgian Institute of Natural Sciences: Brussel, Belgium, 2010.

104. Kerckhof, F.; Rumes, B.; Jacques, T.; Degraer, S.; Norro, A. Early development of the subtidal marine biofouling on a concrete offshore windmill foundation on the Thornton Bank (southern North Sea): First monitoring results. Underw. Technol. 2010, 29, 137-149. [CrossRef]

105. Langhamer, O. Wave Energy Conversion and the Marine Environment: Colonization Patterns and Habitat Dynamics. Ph.D. Thesis, Uppsala University, Uppsala, Sweden, 2009.

106. Lindeboom, H.J.; Kouwenhoven, H.J.; Bergman, M.J.N.; Bouma, S.; Brasseur, S.; Daan, R.; Fijn, R.C.; de Haan, D.; Dirksen, S.; van Hal, R. Short-term ecological effects of an offshore wind farm in the Dutch coastal zone; a compilation. Environ. Res. Lett. 2011, 6, 035101. [CrossRef]

107. Maar, M.; Bolding, K.; Petersen, J.K.; Hansen, J.L.S.; Timmermann, K. Local effects of blue mussels around turbine foundations in an ecosystem model of Nysted off-shore wind farm, Denmark. J. Sea Res. 2009, 62, 159-174. [CrossRef]

108. Shi, W.; Park, H.C.; Baek, J.H.; Kim, C.W.; Kim, Y.C.; Shin, H.K. Study on the marine growth effect on the dynamic response of offshore wind turbines. Int. J. Precis. Eng. Manuf. 2012, 13, 1167-1176. [CrossRef]

109. Van Hoey, G.; Degraer, S.; Vincx, M. Macrobenthic community structure of soft-bottom sediments at the Belgian Continental Shelf. Estuar. Coast. Shelf Sci. 2004, 59, 599-613. [CrossRef]

110. Wilhelmsson, D.; Malm, T. Fouling assemblages on offshore wind power plants and adjacent substrata. Estuar. Coast. Shelf Sci. 2008, 79, 459-466. [CrossRef]

111. Langhamer, O. Artificial reef effect in relation to offshore renewable energy conversion: State of the art. Sci. World J. 2012, 2012. [CrossRef] [PubMed]

112. Fabi, G.; Luccarini, F.; Panfili, M.; Solustri, C.; Spagnolo, A. Effects of an artificial reef on the surrounding soft-bottom community (central Adriatic Sea). ICES J. Mar. Sci. 2002, 59, S343-S349. [CrossRef]

113. Fabi, G.; Fiorentini, L. Comparison between an artificial reef and a control site in the Adriatic Sea: Analysis of four years of monitoring. Bull. Mar. Sci. 1994, 55, 538-558.

114. Sinis, A.I.; Chintiroglou, C.C.; Stergiou, K.I. Preliminary results from the establishment of experimental artificial reefs in the N. Aegean Sea (Chalkidiki, Greece). Belg. J. Zool. 2000, 130, 143-147.

115. Airoldi, L.; Bulleri, F. Anthropogenic disturbance can determine the magnitude of opportunistic species responses on marine urban infrastructures. PLOS ONE 2011, 6, e22985. [CrossRef] [PubMed]

116. Bulleri, F.; Airoldi, L. Artificial marine structures facilitate the spread of a non-indigenous green alga, Codium fragile ssp. tomentosoides, in the north Adriatic Sea. J. Appl. Ecol. 2005, 42, 1063-1072. [CrossRef] 
117. Goren, M. Development of benthic community on artificial substratum at Ashdod (Eastern Mediterranean). Oceanol. Acta 1980, 3, 275-283.

118. Kocak, F.; Ergen, Z.; Çinar, M.E. Fouling organisms and their developments in a polluted and an unpolluted marina in the Aegean Sea (Turkey). Ophelia 1999, 50, 1-20. [CrossRef]

119. Relini, G.; Relini, M.; Montanari, M. An offshore buoy as a small artificial island and a fish-aggregating device (FAD) in the Mediterranean. In Island, Ocean and Deep-Sea Biology; Jones, M.B., Azevedo, J.M.N., Neto, A.I., Costa, A.C., Martins, A.M.F., Eds.; Springer Netherlands: Dordrecht, The Netherlands, 2000; pp. 65-80.

120. Moreno, I.; Roca, I.; Reñones, O.; Coll, J.; Salamanca, M. Artificial reef program in Balearic waters (western Mediterranean). Bull. Mar. Sci. 1994, 55, 667-671.

121. Relini, G.; Tixi, F.; Relini, M.; Torchia, G. The macrofouling on offshore platforms at Ravenna. Int. Biodeterior. Biodegrad. 1998, 41, 41-55. [CrossRef]

122. Badalamenti, F. Are artificial reefs comparable to neighbouring natural rocky areas? A mollusc case study in the Gulf of Castellammare (NW Sicily). ICES J. Mar. Sci. 2002, 59, S127-S131. [CrossRef]

123. Relini, G.; Zamboni, N.; Tixi, F.; Torchia, G. Patterns of sessile Macrobenthos community development on an artificial reef in the gulf of genoa (Northwestern Mediterranean). Bull. Mar. Sci. 1994, 55, 745-771.

124. Ponti, M.; Fava, F.; Perlini, R.A.; Giovanardi, O.; Abbiati, M. Benthic assemblages on artificial reefs in the northwestern Adriatic Sea: Does structure type and age matter? Mar. Environ. Res. 2015, 104, 10-19. [CrossRef] [PubMed]

125. Nicoletti, L.; Marzialetti, S.; Paganelli, D.; Ardizzone, G.D. Long-term changes in a benthic assemblage associated with artificial reefs. In Biodiversity in Enclosed Seas and Artificial Marine Habitats; Relini, G., Ryland, J., Eds.; Springer Netherlands: Dordrecht, The Netherlands, 2007; pp. 233-240.

126. Galil, B.S.; Boero, F.; Campbell, M.L.; Carlton, J.T.; Cook, E.; Fraschetti, S.; Gollasch, S.; Hewitt, C.L.; Jelmert, A.; Macpherson, E.; et al. "Double trouble": The expansion of the Suez Canal and marine bioinvasions in the Mediterranean Sea. Biol. Invasions 2014, 17, 973-976. [CrossRef]

127. Çinar, M.E. Serpulid species (Polychaeta: Serpulidae) from the Levantine coast of Turkey (eastern Mediterranean), with special emphasis on alien species. Aquat. Invasions 2006, 1, 223-240. [CrossRef]

128. Adams, T.P.; Miller, R.G.; Aleynik, D.; Burrows, M.T. Offshore marine renewable energy devices as stepping stones across biogeographical boundaries. J. Appl. Ecol. 2014, 51, 330-338. [CrossRef]

129. Siokou-Frangou, I.; Christaki, U.; Mazzocchi, M.G.; Montresor, M.; Ribera d'Alcalá, M.; Vaqué, D.; Zingone, A. Plankton in the open Mediterranean Sea: A review. Biogeosciences 2010, 7, 1543-1586. [CrossRef]

130. Cerino, F.; Bernardi Aubry, F.; Coppola, J.; La Ferla, R.; Maimone, G.; Socal, G.; Totti, C. Spatial and temporal variability of pico-, nano- and microphytoplankton in the offshore waters of the southern Adriatic Sea (Mediterranean Sea). Cont. Shelf Res. 2012, 44, 94-105. [CrossRef]

131. Shields, M.A.; Woolf, D.K.; Grist, E.P.M.; Kerr, S.A.; Jackson, A.C.; Harris, R.E.; Bell, M.C.; Beharie, R.; Want, A.; Osalusi, E.; et al. Marine renewable energy: The ecological implications of altering the hydrodynamics of the marine environment. Ocean Coast. Manag. 2011, 54, 2-9. [CrossRef]

132. Broström, G. On the influence of large wind farms on the upper ocean circulation. J. Mar. Syst. 2008, 74, 585-591. [CrossRef]

133. Paskyabi, M.B.; Fer, I. Upper ocean response to large wind farm effect in the presence of surface gravity waves. Energy Procedia 2012, 24, 245-254. [CrossRef]

134. Adams, T.P.; Aleynik, D.; Burrows, M. Larval dispersal of intertidal organisms and the influence of coastline geography. Ecography 2014, 37, 698-710. [CrossRef]

135. Inger, R.; Attrill, M.J.; Bearhop, S.; Broderick, A.C.; James Grecian, W.; Hodgson, D.J.; Mills, C.; Sheehan, E.; Votier, S.C.; Witt, M.J. Marine renewable energy: Potential benefits to biodiversity? An urgent call for research. J. Appl. Ecol. 2009, 46, 1145-1153. [CrossRef]

136. Miller, R.G.; Hutchison, Z.L.; Macleod, A.K.; Burrows, M.T.; Cook, E.J.; Last, K.S.; Wilson, B. Marine renewable energy development: Assessing the Benthic Footprint at multiple scales. Front. Ecol. Environ. 2013, 11, 433-440. [CrossRef]

(C) 2016 by the authors; licensee MDPI, Basel, Switzerland. This article is an open access article distributed under the terms and conditions of the Creative Commons by Attribution (CC-BY) license (http://creativecommons.org/licenses/by/4.0/). 